University of Nebraska - Lincoln

DigitalCommons@University of Nebraska - Lincoln

Faculty Publications - Textiles, Merchandising and Fashion Design

Textiles, Merchandising and Fashion Design,

Department of

2013

Potential of using plant proteins and chicken feathers for cotton warp sizing

Yiqi Yang

University of Nebraska-Lincoln, yyang2@unl.edu

Narendra Reddy

University of Nebraska - Lincoln, nreddy3@unl.edu

Follow this and additional works at: https://digitalcommons.unl.edu/textiles_facpub

Yang, Yiqi and Reddy, Narendra, "Potential of using plant proteins and chicken feathers for cotton warp sizing" (2013). Faculty Publications - Textiles, Merchandising and Fashion Design. 29.

https://digitalcommons.unl.edu/textiles_facpub/29

This Article is brought to you for free and open access by the Textiles, Merchandising and Fashion Design, Department of at DigitalCommons@University of Nebraska - Lincoln. It has been accepted for inclusion in Faculty Publications - Textiles, Merchandising and Fashion Design by an authorized administrator of DigitalCommons@University of Nebraska - Lincoln. 


\title{
Potential of using plant proteins and chicken feathers for cotton warp sizing
}

\author{
Yiqi Yang ${ }^{1,2,3}$ and Narendra Reddy ${ }^{1}$
}

1. Department of Textiles, Merchandising and Fashion Design, University of Nebraska-Lincoln, 234 HECO Building, East Campus, Lincoln, NE 68583-0802, USA

2. Department of Biological Systems Engineering, University of Nebraska-Lincoln, 234 HECO Building, East Campus, Lincoln, NE 68583-0802, USA

3. Nebraska Center for Materials and Nanoscience, University of Nebraska-Lincoln, 234 HECO Building, East Campus, Lincoln, NE 68583-0802, USA

Corresponding author - Narendra Reddy, email nreddy3@unl.edu

\begin{abstract}
Two plant proteins, soyprotein and wheat gluten, and chicken feathers used to size cotton substrates provided sizing performance similar to starch and were also easily degraded in activated sludge. Sizing is an essential process to impart protection to warp yarns and increase weaving efficiency. Cotton yarns have traditionally been sized with starch, modified starch derivatives, CMC, poly vinyl alcohol (PVA), or a combination thereof along with quite a few other fiber binding ingredients. Although starch and starch derivatives are extensively used for sizing, there can be several limitations including less-than-satisfactory sizing performance and difficulties in desizing starch based size. Plant proteins such as wheat gluten, soyproteins and poultry feathers are available in large quantities at low cost and have limited industrial applications. However, these proteins are known to have excellent film-forming properties, a primary requirement for a warp size, and have also been used as adhesives. Using proteins as warp sizing agents on cotton yarns potentially could provide acceptable sizing performance and be cost-effective, as well. In this research, soypro-
\end{abstract}

teins, wheat gluten, and chicken feathers were studied for exploring their feasibility for sizing, desizing, biodegradability, and ability to replace starch and PVA for sizing cotton yarns. It was found that all three proteins provided similar cohesion to fibers and abrasion resistance compared to starch. Protein sizes had significantly high $\mathrm{BOD}_{5} / \mathrm{COD}$ ratio compared to PVA, suggesting that the proteins are easily degradable in textile effluent treatment plants.

Keywords: novel cotton size, proteins/inter-fiber cohesion, abrasion resistance, biodegradability, feasibility study

\section{Introduction}

The textile industry is one of the largest industries and textile processing consumes large amounts of water and chemicals, which makes the industry one of the major contributors to industrial pollution across the world. About 95-400 litres (L) of water per kg of fabric are generally required during the processing of textiles, leading to considerable pollution (UNEP 1996). 
Pollution loads from textile industry vary depending on the type of fibers and processes involved. Although technologies have been developed to reduce or recover water consumed during textile processing, they are not adopted in developing countries where most of the textile manufacturing is currently done. Warp sizing and the subsequent fabric desizing still account for a major part of the water consumption and pollution from the textile industry in developing countries. Fabrics contain size varying from 8 to $15 \%$ and typical pollution loads from desizing $100 \%$ cotton woven fabrics sized with starch include BOD of $45.5 \mathrm{~kg}$, COD of $91 \mathrm{~kg} / 1,000 \mathrm{~kg}$ of fabric processed with consumption of about $350 \mathrm{~L}$ of water $/ \mathrm{kg}$ of fabric processed (Barclay and Buckley 2000).

Starch and starch derivatives have been the predominant sizing agents used for cotton warp sizing (Goswami et al. 2004). Relatively low cost compared to other sizing chemicals such as PVA and their blends, ease of preparation and ready biodegradability are some of the reasons for using starch as the sizing agent. However, there are a number of issues when starch is used for sizing. For instance, native (unmodified) starch solutions have poor viscosity stability and it is difficult to desize (remove size) fabrics containing starch. Starch films formed on the surface of fibers are considerably brittle and therefore the starch-sized materials are not easily processable at low humidity levels (Liu et al. 2010). Further, fabrics sized with starch are mostly desized using enzymes and/or acid or alkaline hydrolysis at high temperatures $\left(80-90{ }^{\circ} \mathrm{C}\right)$. The desizing process makes starch unrecoverable and unusable even if recovered (Tarakcioglu 1986; Anis et al. 2007). In addition, the price and availability of starch is a concern due to the use of starch as a scarce source of food in many poor and developing countries and, lately, as a source for biofuels. Although starch is biodegradable, the BOD values for starch used as size are considerably higher than those for PVA (2.5 L/1,000 kg), suggesting that starch present in waste water treatment plants causes considerable burden to the effluent treatment process (Marrot and Roche 2002). Several attempts have been made to modify starch, starch 'cooking' for size, and/or to find alternative sizing agents that can substitute starch (Dumitras et al. 2005; El-Sawy et al. 1993; Hari and Bhalla 1986). Recent attempts by the American (ARS-USDA) and Moldovan scientists to reduce or even eliminate warp sizing in modern weaving have been reasonably successful (Sawhney et al. 2005a, b).
Chemical modifications such as oxidation, hydrolysis, esterification and etherification, and grafting, addition of plasticizers and or synthetic polymers have also been used to make starch more suitable for sizing cotton (Liu et al. 2010; Hebeish et al. 2005, 2008). In a study on cationized starch derived from pre-oxidized starch, it was reported that oxidization conditions especially $\mathrm{pH} 6$ influenced strength and elongation improvements (Hebeish et al. 2005, 2008). Nitrogen groups were added onto maize starch by cyanoethylation, carbamoylethylation and carbamation and the changes in size viscosity and mechanical properties of sized cotton yarns were measured (Mostafa 2003; Mostafa and Morsy 2004). In a similar study, sesbania gum was oxidized using sodium hypochlorite and the effects of oxidation on the size viscosity and the mechanical properties of the sized fine cotton yarns were investigated (Shen et al. 2011). It was reported that oxidation increased strength and abrasion resistance but decreased elongation and hairiness of the sized yarn (Shen et al. 2011). Similar results were observed when maize starch was oxidized using sodium chlorite and thiourea system (Abdel-Hafiz 1995). Carboxymethylation of maize starch at $30{ }^{\circ} \mathrm{C}$ resulted in a completely water-soluble size product that increased tensile strength of the sized samples by about $38.6 \%$ and the desizing efficiency was $98 \%$ at $30{ }^{\circ} \mathrm{C}$ (El-sheikh 2010).

Grafting of synthetic monomers on to starch is another approach that has been used to modify starch for sizing applications. Acrylic acid was grafted onto corn starch after an allyl pre-treatment and used to size cotton rovings. The starch-g-poly(acrylic acid) had a degree of substitution between 0.011 and 0.037 and was found to improve the properties of the sized roving (Zhu et al. 2009). Pregelled starch was subject to acid hydrolysis and grafted with methylacrylamide (MAam) or methacrylonitrile (MAN). When sized on cotton yarns, the MAam and MAN grafted starches provided better mechanical properties than ungrafted or carboxymethylated starches (Mostafa and Morsy 2004). The performance of amphoteric starch containing quaternary ammonium and carboxylic groups on the adhesion to cotton and the modified starch's film properties were investigated (Zhu et al. 2008). The adhesion to fibers and the film properties were found to be determined by the degree of substitution and the presence of cationic or anionic groups. Innovative starch derivatives for starch sizing were developed by grafting starch with monochlorotriazinyl- $\beta$ - 
cyclodextrin and cationizing the grafted starch with Quat-188 (Hebeish et al. 2008). The molecular size of the grafted polymer, the amount of grafting and the extent of cationization were reported to determine the sizing performance (Hebeish et al. 2008). However, grafting of synthetic monomers substantially increases the cost of the size and may also decrease the biodegradability of starch.

In addition to starch and starch derivatives, other biopolymers such as chitosan and carboxymethyl cellulose (CMC) have been used for sizing. CMC was grafted with polyvinyl acetate (PVAc) to produce CMC-g-PVA and found to provide better properties to the $100 \%$ cotton and 50/50 polyester/cotton fabrics than a physical blend of CMC and PVA (Mohamed et al. 2010).

Plant proteins such as soyproteins and wheat gluten are obtained as byproducts during the processing of grains for food/fuel and have been used for food and non-food applications. Poultry feathers generated as byproducts have limited use and are mostly disposed in landfills and are inexpensive (Reddy and Yang 2010). Attempts have also been made to utilize the plant proteins and feathers for textile applications. Regenerated protein fibers have been developed from plant proteins including wheat gluten and soyproteins and also from goat milk (Reddy and Yang 2011). Native feathers have been characterized as textile fibers and attempts have also been made to dissolve and regenerate protein fibers from feather keratin (Reddy and Yang 2007). Wheat gluten was reported to be an excellent binder for textile printing paste (Hamilton and Chiweshe 1998). The properties and low cost of plant proteins and feathers makes them attractive choice for textile warp sizing. Recently, we have demonstrated that wheat gluten and soyproteins can provide polyester and polyester/cotton rovings, yarns and fabrics sizing performance similar to that of PVA (Chen et al. 2013a, b).

In this research, we have sized cotton rovings to demonstrate the idea of using plant proteins as sizing agents although only yarns are sized in actual practice. Fabrics were sized to study the changes in abrasion resistance and desizing attributes under various desizing conditions. Influence of the size preparation conditions on the cohesiveness of rovings and abrasion resistance of the rovings has been studied. Ability of the proteins to degrade in activated sludge and the effect of nitrogen released from the proteins on biodegradability have also been investigated in comparison to PVA and starch.

\section{Materials and methods}

\section{Materials}

Wheat gluten (Whetpro 80) and soyproteins (Profam 648) with approximately 80 and $90 \%$ protein content, respectively, were supplied by Archer Daniels Midlands Company, Decatur, IL. Chicken feather consisting of quills, barbs and barbules were obtained from Feather Fiber Corporation, Nixa, MO. Untreated corn starch (National Starch and Chemical Company (Bridgewater NJ) was used to compare the sizing performance of the proteins. Polyvinyl alcohol (PVA) used as a warp size was obtained from a major commercial size supplier in the US and had a molecular weight of 65,000 Da and viscosity of $11.6-15.4 \mathrm{mPa} \cdot \mathrm{s}$ for a $4 \mathrm{wt} \%$ solution at $21^{\circ} \mathrm{C}$. The proteins were used as received and the feathers were ground into powder in a Wiley mill. Cotton roving (0.49 hank) used in this study was made from Fiber Max cotton $(27.8 \mathrm{~mm}$ length, 4.6 average micronaire, strict low middling, light spot and grown in southeastern USA) were supplied by Mount Vernon Mills, Alto, GA. Finished fabric (Type 400) used in the study was purchased from Test Fabrics Inc, West Piston, PA. Chemicals such as sodium hydroxide used were reagent grade and purchased from VWR International, Bristol, CT. Activated sludge for the biodegradation study was collected from the local municipal sewage treatment facility. Biodegradation test kits to determine chemical oxygen demand (COD) were purchased from Hach Company.

\section{Methods}

\section{Pre-treating proteins to prepare the size solution}

The proteins were pre-treated in alkali solution $(0.25-2 \% \mathrm{w} / \mathrm{w})$ to hydrolyze the proteins and obtain a solution suitable for sizing. Depending on the percentage add-on desired, the proteins were heated in the alkali solution up to $90^{\circ} \mathrm{C}$ and held at that temperature for $30 \mathrm{~min}$. Later, the solution was cooled down to about $60{ }^{\circ} \mathrm{C}$ and the $\mathrm{pH}$ was adjusted between 7 and 
10 by the addition of hydrochloric acid. The solution was re-heated to $90^{\circ} \mathrm{C}$ and used to size the cotton rovings, and fabrics. Starch, on the other hand, was heated in water to $90^{\circ} \mathrm{C}$ and held for $30 \mathrm{~min}$ before using for sizing. PVA was heated in water up to $90{ }^{\circ} \mathrm{C}$ and used for sizing according to the recommendation from the manufacturer.

Sizing

Rovings were wound onto frames to provide adequate tension and used for sizing. The frames were placed in shallow glass trays and the sizing solution was added into the trays ensuring that the materials were completely immersed. After $5 \mathrm{~min}$, the frames were removed from the sizing solution and allowed to dry under standard conditions. In the case of fabrics, the sized fabrics were passed through a laboratory padder to ensure uniform penetration. Padded fabrics were weighed to ensure a constant pick-up was obtained. The weight of the materials before and after sizing and drying in an oven at $105^{\circ} \mathrm{C}$ for $3 \mathrm{~h}$ were determined to calculate the percentage add-on.

\section{Desizing}

Fabrics sized with the proteins and starches with a known amount of percentage add-on were desized under various conditions. Cold sizing, i.e., sizing at room temperature $\left(20^{\circ} \mathrm{C}\right)$ was done using water-to-fabric ratio of 10:1 and by treating the fabrics for $5 \mathrm{~min}$. Later, the fabrics were washed once again using water-tofabric ratio of 10:1. In addition to the cold sizing, the fabrics were also desized using $90{ }^{\circ} \mathrm{C}$ water but with water to fabric ratio of 5:1 for $5 \mathrm{~min}$. Desizing water was discarded and the fabrics were rinsed once with fresh $90{ }^{\circ} \mathrm{C}$ water. Desized fabrics were dried at $105^{\circ} \mathrm{C}$ and their weight was determined to calculate the percentage desizing.

\section{Viscosity of the sizing solution}

Viscosity of the sizing solution was measured on a Brookfield rheometer (R/S Plus) at $25^{\circ} \mathrm{C}$ using a CC48 spindle and cup and a solution concentration ranging from 1 to $6 \%$. At least three separate samples were tested for each condition and the average viscosity was calculated.
Measuring sizing performance

Cohesiveness of fibers - Ability of the sizing solution to adhere the fibers together was used as an assessment of the inter-fiber cohesion or cohesiveveness. Since rovings are a bundle of loose fibers without strength, the improvement in the strength of the rovings is considered to be an indication of the cohesiveness among the fibers. To measure the cohesiveness, the tensile properties of the rovings were determined on a tensile tester (MTS, Model QTest 10; Eden Prairie, MN) using a $500 \mathrm{~N}$ load cell, gauge length of $10 \mathrm{~cm}$ and crosshead speed of $50 \mathrm{~mm} / \mathrm{min}$. About 20 samples each from three frames that were separately sized were tested for each condition. The average and standard deviation of the tensile properties were reported.

Abrasion resistance - Fabric abrasion resistance was measured on a Universal Wear Tester according to ASTM standard D3886. Fabric samples were placed on the tester and abraded with a 0 grade emery paper and $1 / 2 \mathrm{lb}$ weight. The number of cycles required to abrade the fabric and create a hole in the fabric was determined.

Effect of humidity - Sizing performance is related to the humidity in the weaving room. Since the proteinbased materials are hydrophilic, the effects of humidity on the tensile properties of the rovings were studied. After sizing, the frames were placed in a humidity chamber (Caron Environmental Chamber) at 55 or $75 \%$ relative humidity and $21^{\circ} \mathrm{C}$ for $24 \mathrm{~h}$. After conditioning, the rovings were immediately tested for their tensile properties.

Film properties - Wheat gluten, soyproteins and chicken feathers $(6 \% \mathrm{w} / \mathrm{w})$ were dissolved in aqueous alkali solution at $90{ }^{\circ} \mathrm{C}$ for $30 \mathrm{~min}$. The treated solution was cooled to about $70^{\circ} \mathrm{C}$ and later poured onto glass plates. The solution was evaporated under ambient conditions for about $48 \mathrm{~h}$ to obtain films. Starch and PVA $(5 \% \mathrm{w} / \mathrm{w})$ was heated in water up to $90{ }^{\circ} \mathrm{C}$, cooled down and then cast onto plates to form films. The films obtained were conditioned under standard conditions of $21{ }^{\circ} \mathrm{C}$ and $65 \%$ humidity for $24 \mathrm{~h}$ and then tested for their tensile properties. The tensile properties of the films were determined accord- 
ing to ASTM standard D882 on a MTS tensile tester using a crosshead speed of $50 \mathrm{~mm} / \mathrm{min}$. Three films were cast from solutions that were separately prepared and eight samples were cut from each film for a total of about 24 film samples for each condition studied. Average and \pm one standard deviation of the tensile properties are reported.

\section{Biodegradation}

Biodegradability of the proteins and starch in activated sludge was studied to determine the ability of the proteins to degrade in textile effluent treatment plant. Activated sludge obtained from the local waste water treatment plant was acclimatized to our laboratory conditions for 2 days and later used for the biodegradation study. COD, biochemical oxygen demand $\left(\mathrm{BOD}_{5}\right)$ and nitrogen (total and ammonia nitrogen) released from the proteins was measured for up to 10 days. The sludge was aerated using oxygen pumps and nutrients were added to keep the microorganisms alive. Based on the normal percentage addon (10-15\%) of size, the concentration of size in effluent treatment plants is about $100-150$ ppm. However, a much higher concentration of $300 \mathrm{ppm}$ of the size solution was added into the sludge for the biodegradation studies.

Chemical oxygen demand: COD was determined according to the United States Environmental Protection Agency standard method 8000 using a $\mathrm{HACH}$ high range (20-1,500 mg/L) COD test kit (TNT 822). After a pre-determined degradation in the activated sludge, the sludge containing the size solution was added into the test kit and digested at $150{ }^{\circ} \mathrm{C}$ for $2 \mathrm{~h}$. The sample was then cooled down and the absorbance of the sample was measured on a spectrophotometer (HACH Company, Model: DR3900) at a wave length of $620 \mathrm{~nm}$. The spectrophotometer directly reads the concentration of COD in $\mathrm{mg} / \mathrm{L}$.

Five day biochemical oxygen demand $\left(\mathrm{BOD}_{5}\right)$ : The 5 days biochemical oxygen demand to measure the ability of the protein solution to be degraded by the microorganisms in the sludge was performed according to the standard methods provided by American Public Health Association. BOD $_{5}$ tests were performed before the activated sludge treatment and when the COD had reached $100 \mathrm{mg} / \mathrm{L}$ or lower.
Test was conducted in specified $\mathrm{BOD}_{5}$ bottles, samples were kept in the dark at $20^{\circ} \mathrm{C}$ and the changes in the oxygen concentration were measured using a dissolved oxygen probe (Hach company: Model HQ440D multi). It was ensured that appropriate seeding was done and the oxygen depletion for the blank water was less than $0.2 \mathrm{mg} / \mathrm{L}$. At least three separate treatments were done for each protein, each day and the average and \pm one standard deviation of the $\mathrm{BOD}_{5}$ has been reported.

\section{Total and ammonia nitrogen}

Total nitrogen released from the proteins during degradation in activated sludge was measured based on the alkaline persulfate oxidation digestion method. Potassium persulfate was added into the samples and digested at $120^{\circ} \mathrm{C}$ for $40 \mathrm{~min}$. Later, $1 \mathrm{ml}$ of $\mathrm{HCl}$ was added to terminate the digestion and the absorbance of the sample was measured on a spectrophotometer at 220 and $275 \mathrm{~nm}$. The concentration of nitrogen was determined based on the absorbance using calibration curves with regression co-efficient $\left(R^{2}>0.999\right)$ that were prepared earlier.

Ammonia nitrogen was calculated by adding salicylic acid, potassium sodium tartrate, sodium nitroferricyanide and sodium hypochlorite in an alkaline phosphate buffer into the samples containing sludge and the size solution. Samples were allowed to stand for $1 \mathrm{~h}$ at room temperature. Addition of the chemicals turned the samples into a green color and the intensity of the color was proportional to the amount of nitrogen in the samples. Absorption of the samples was measured on a spectrophotometer (Beckman Coulter: Model DU 720) and the amount of ammonia nitrogen was calculated based on the calibration curves prepared with known concentration of ammonia.

\section{Statistics}

All the experimental results were analyzed using ANOVA with a $\mathrm{p}$ value of $<0.05$ considered to be significant. Error bars were used to indicate standard deviation and in each graph, the data points with different letters indicated statistically significant difference. 

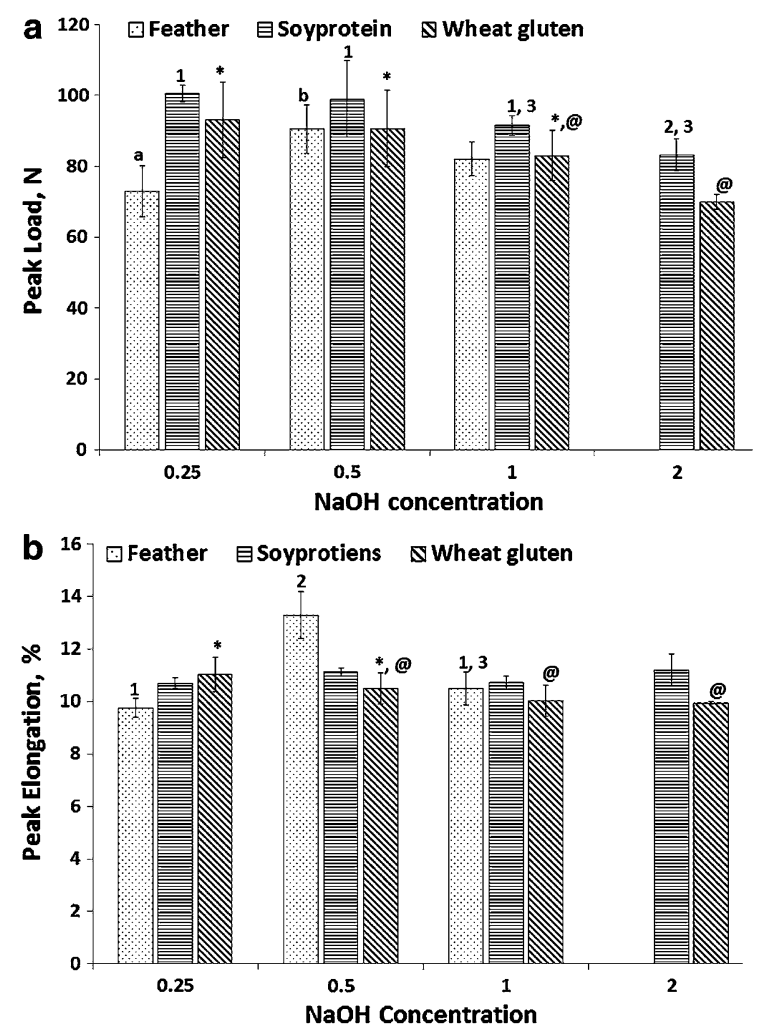

Figure 1. Influence of concentration of alkali used during pretreatment of the proteins on the tensile strength (a) and elongation (b) of cotton rovings. The rovings were sized using $\mathrm{pH}$ 8 solution at $90{ }^{\circ} \mathrm{C}$ for $5 \mathrm{~min}$. Add-on was $11.7 \%$ for feather and wheat gluten and $7.7 \%$ for the soyprotein sized rovings. For each protein, data points without any or with the same letter or symbol represent data points that are not statistically significantly different.

\section{Results and discussion}

Effect of size preparatory conditions

Concentration of sodium hydroxide: The concentration of sodium hydroxide used to pre-treat the protein had varying effect on the tensile properties of the cotton rovings. As seen from Figure 1a, increasing the concentration of sodium hydroxide used for pretreatment initially (from 0.25 to $0.5 \%$ ) improved the strength of the rovings treated with feathers but decreased the strength of all the rovings considerably at high alkali concentrations. Rovings treated with wheat gluten and soyproteins had highest strength when treated with $0.25 \% \mathrm{NaOH}$ but the feather treated roving had considerably lower strength at this concentration. Feathers are highly crosslinked structures and it was difficult to dissolve feathers and form good films

at low alkali concentrations. Therefore, rovings sized with feathers treated at low alkali concentrations had lower strength. Alkali concentrations of 0.25 and $0.5 \%$ provided similar strength for wheat gluten and soyprotein treated rovings but the strength decreased at higher alkali concentrations due to the hydrolysis of proteins. However, concentrations lower than $0.25 \%$ did not dissolve the proteins completely and were therefore not used for sizing.

There was marginal effect of alkali concentration on the breaking elongation of the wheat gluten and soyprotein treated rovings but the elongation of the rovings sized with feather treated with $0.5 \%$ alkali was significantly higher than that of the 0.25 or $1 \%$ alkali treated roving as seen from Figure $1 \mathrm{~b}$. Feathers treated with $0.5 \%$ alkali formed a better film and, with limited hydrolysis, provided higher strength and elongation to the rovings. Similarly, ability of soyprotein to provide better strength to the rovings even at relatively lower percentage add-on most likely was due to the protein's superior film-forming properties and adhesion to cotton fibers. At a molecular level, feather proteins are longer and linear polymers than soyproteins (globular) and wheat gluten and probably can provide better elongation to the rovings.

Effect of $\mathrm{pH}$ of sizing solution: $\mathrm{pH}$ of the sizing solution had similar influence on all three proteins used for sizing, as seen from Figure 2a, b. Tensile strength of the roving depicted in Figure $2 \mathrm{a}$ was low at $\mathrm{pH} 7$ and at $\mathrm{pHs} 9$ and 10 compared to the strength at $\mathrm{pH} 8$. At low $\mathrm{pH}$, there was considerable salt (due to addition of acid into the alkaline sizing solution) which affected the chemical interaction between the proteins and the cotton fibers. Also, alkaline $\mathrm{pHs}$ at high temperature $\left(90{ }^{\circ} \mathrm{C}\right)$ during sizing may hydrolyze the proteins resulting in poor film properties and therefore lower strength. Sizing agents such as modified starches are usually applied onto cotton between $\mathrm{pH}$ 7-8. Best performance of the protein size was also at $\mathrm{pH} 8$ suggesting that the protein sizes would be convenient to use on a textile slasher (size applicator). Changing $\mathrm{pH}$ did not affect the elongation of the rovings sized with soyproteins but the elongation of the wheat gluten and feather sized rovings decreased at high $\mathrm{pH}$ compared to the elongation at $\mathrm{pH} 8$, as seen from Figure $2 \mathrm{~b}$. $\mathrm{pH}$ of the sizing solution did not affect the elongation of the rovings treated with soyproteins, seemingly due to the much lower percentage add-on and therefore thinner size films on the fiber surface as discussed later. 

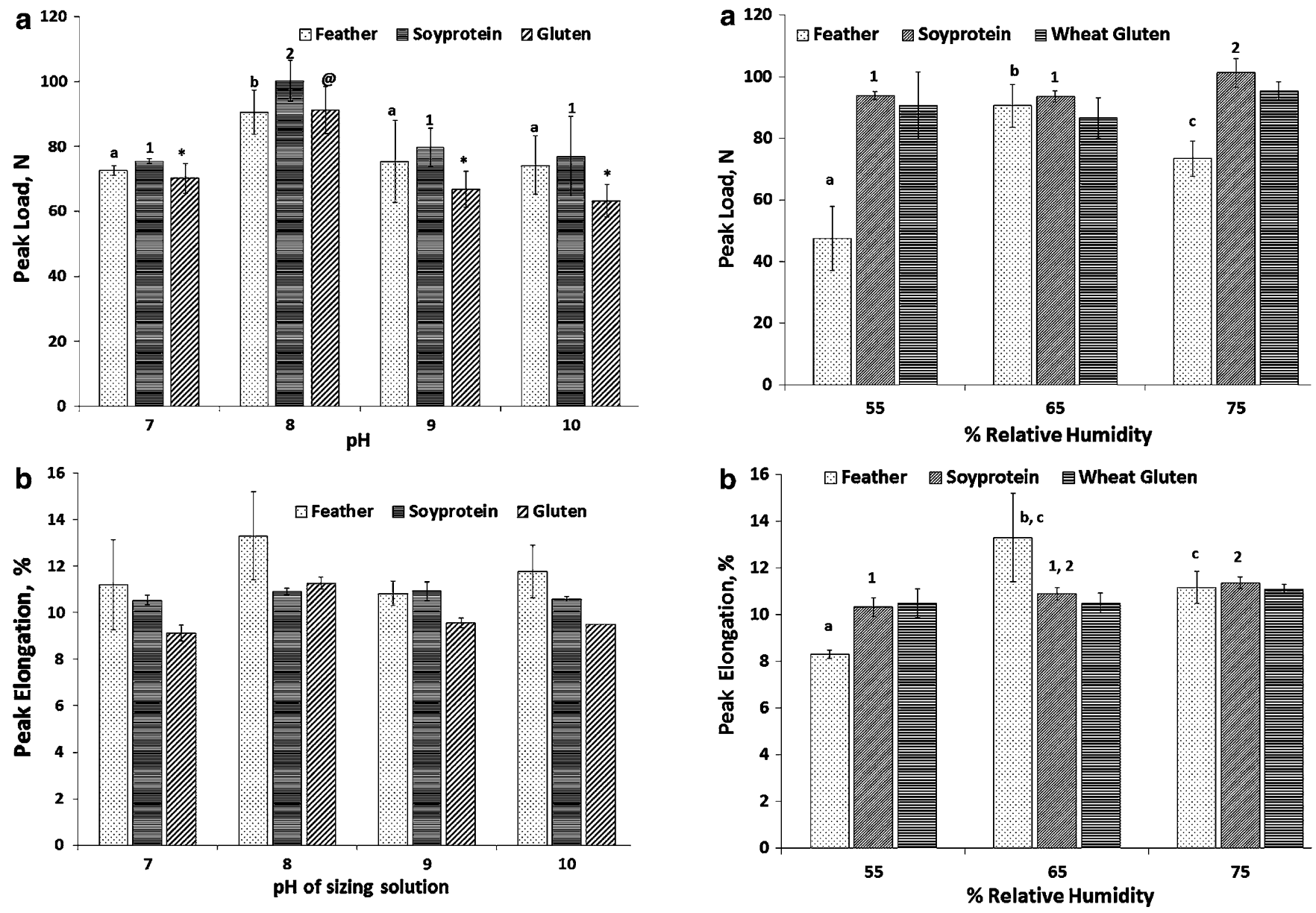

Figure 2. Effect of $\mathrm{pH}$ of sizing solution on the tensile load (a) and breaking elongation $\%(b)$ of cotton rovings sized with feather (11.5\% add-on), wheat gluten (11.5\% add-on) and soyprotein $\left(7.5 \%\right.$ add-on) after sizing at $90{ }^{\circ} \mathrm{C}$ for $5 \mathrm{~min}$. For each protein, data points without any or with the same letter or symbol represent data points that are not statistically significantly different.

\section{Effect of relative humidity}

Relative humidity influenced the properties of the rovings sized with feather to a greater extent compared to the rovings sized with wheat gluten or soyproteins as seen from Figure 3a, b. Feather-sized rovings had considerably lower strength (Figure 3a) and elongation (Figure $3 \mathrm{~b}$ ) when the humidity was $55 \%$ and also at $75 \%$, whereas the strength and elongation of the soyprotein- and wheat gluten-treated rovings did not show any appreciable change with change in humidity. Feather films were sensitive to moisture and became brittle at low humidity (55\%). Higher moisture at $65 \%$ humidity acted as a lubri-

Figure 3. Effect of relative humidity on the strength and elongation of the rovings sized with feather (11.5\% add-on), wheat gluten (11.5\% add-on) and soyproteins (7.5\% add-on). Sizing was done at $90^{\circ} \mathrm{C}$ for $5 \mathrm{~min}$ and the $\mathrm{pH}$ of the sizing solution was 8 . For each protein, data points without any or with the same letter or symbol represent data points that are not statistically significantly different.

cant, made the feather proteins more flexible and provided higher elongation and strength to the rovings. However, excessive moisture would make the films soft and flexible and decreased the tensile properties as seen for the feather proteins at $75 \% \mathrm{hu}$ midity. Feather sizing solution was pre-treated using $0.5 \%$ alkali compared to $0.25 \%$ for wheat gluten and soyproteins and therefore contained considerable amounts of salt. Salts on the rovings absorb water and therefore the feather sized rovings probably were more sensitive to changes in humidity. Similar changes in the performance of cotton yarns at different humidities have been reported earlier (Hari and Tewary 1985). 
Abrasion resistance

Gluten and soyprotein provided similar abrasion resistance to the size-coated cotton fabrics whereas fabrics sized with feather size had relatively low resistance as seen from Figure 4. Abrasion resistance of a coated or sized material (roving, yarn, or fabric) is mainly related to the film forming and adhesive properties of the size. Soyproteins and wheat gluten films had tensile strength of 1.6 and $2 \mathrm{MPa}$, respectively compared to $1 \mathrm{MPa}$ for feather films. Elongations of soyprotein and wheat gluten films were 1.9 and $1.6 \%$, respectively and $1.3 \%$ for feathers. Starch films were very brittle and could not be tested without the addition of plasticizer. Wheat gluten and soyproteins form good films with better strength and elongation than starch and therefore provide better abrasion resistance to the cotton fabrics. In addition to being weaker, feather films absorb considerable amounts of moisture that possibly makes the films to be too soft and clumsy, leading to lower abrasion resistance.

\section{Desizing}

Fabrics sized with the proteins and starch showed satisfactory desizeability with greater than $90 \%$ size removal even at room temperature as shown in Table 1. Although attempts are being made to desize fabrics at low or room temperature, most starch desizing is done at high temperatures due to the difficulty

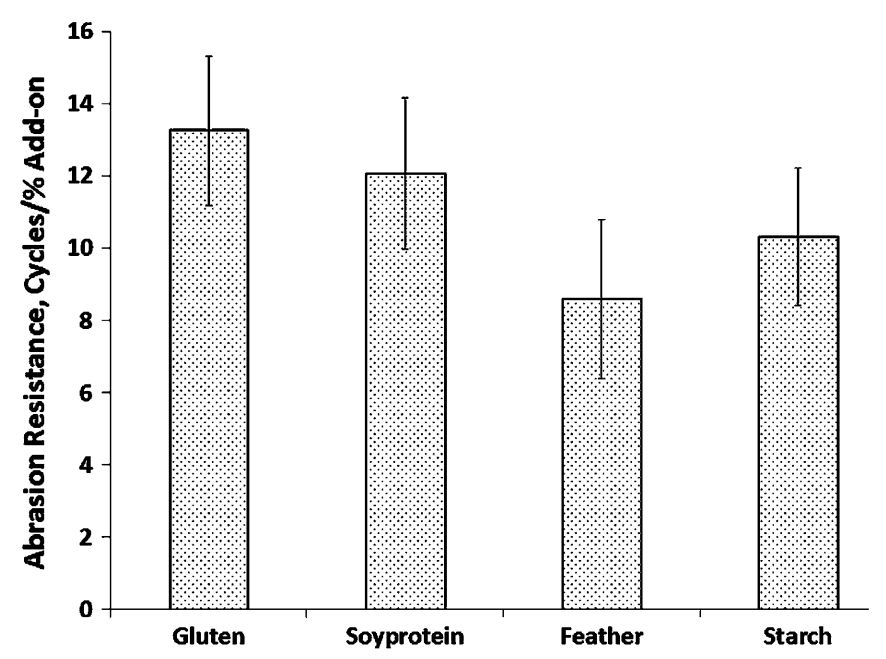

Figure 4. Comparison of the abrasion resistance of cotton fabrics treated with the proteins and starch size. in removing waxes and other additives present in sizing chemicals (El-Sheikh 2010). Wheat gluten and soyprotein had about $98 \%$ removal when desized at room temperature, feather had a $100 \%$ size removal but starch had a lower size removal of $94.8 \%$. No major difference was observed when the fabrics were desized using $90{ }^{\circ} \mathrm{C}$ water but with a water to fabric ratio of $5: 1$. Ability of the proteins to be desized at room temperature would save energy but needs higher amounts of water. Alternatively, lower amounts of water could be used by using higher temperature during desizing depending on the economics and requirements for desizing. Easy removal of size means that the proteins would not affect further processing of the fabrics.

\section{Biodegradation}

\section{Chemical oxygen demand}

From Figure 5a, it is apparent that the protein solutions had substantially easier degradation in activated sludge compared to PVA and similar to that of starch, except for feathers. At a concentration of $300 \mathrm{ppm}$ and before treating in the activated sludge, the proteins, starch and PVA had similar COD. There was more than a $50 \%$ decrease in COD for the gluten and soyprotein samples and about $32 \%$ decrease for starch just after 1 day of treating in the activated sludge whereas there was almost no decrease for feathers and PVA. Prolonging the degradation considerably

Table 1. Comparison of the percentage desizing ability of cotton fabrics treated with proteins and starch when desized at 20 and $90^{\circ} \mathrm{C}$

\begin{tabular}{|c|c|c|c|}
\hline \multirow[t]{2}{*}{ Type of size } & \multicolumn{2}{|c|}{ Desizing conditions } & \multirow[t]{2}{*}{ \% Desized } \\
\hline & Temp, ${ }^{\circ} \mathrm{C}$ & $\begin{array}{l}\text { Water to } \\
\text { fabric ratio }\end{array}$ & \\
\hline \multirow[t]{2}{*}{ Soyprotein } & 20 & $10: 1$ & $98.9 \pm 0.05$ \\
\hline & 90 & $5: 1$ & $98.7 \pm 0.44$ \\
\hline \multirow[t]{2}{*}{ Wheat gluten } & 20 & $10: 1$ & $98.4 \pm 0.01$ \\
\hline & 90 & $5: 1$ & $98.4 \pm 0.28$ \\
\hline \multirow[t]{2}{*}{ Feather } & 20 & 10:1 & $100 \pm 0.81$ \\
\hline & 90 & $5: 1$ & $99.8 \pm 0.28$ \\
\hline \multirow[t]{2}{*}{ Starch } & 20 & 10:1 & $94.8 \pm 1.1$ \\
\hline & 90 & $5: 1$ & $94.5 \pm 0.93$ \\
\hline
\end{tabular}

Add-on percentage on the fabrics was about $6 \%$ and the sizing was done for $5 \mathrm{~min}$. 

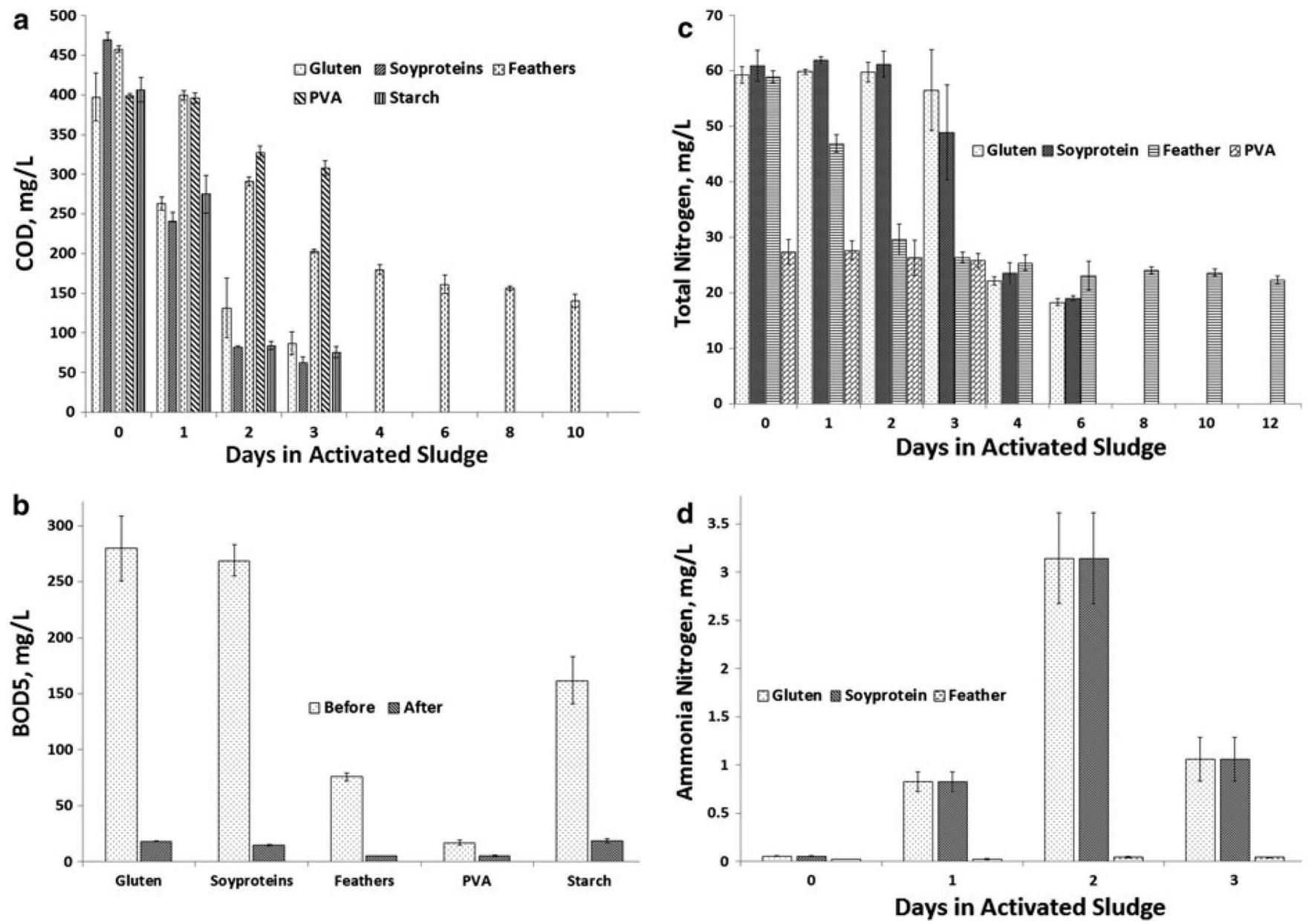

Figure 5. a) Changes in the COD of the proteins and starch in comparison to PVA when treated in activated sludge for up to 10 days. Concentration of the sizing agents in the sludge was $300 \mathrm{ppm}$ and the sludge was aerated and maintained at $21^{\circ} \mathrm{C}$ during the degradation. $\mathbf{b}$ ) Changes in the $\mathrm{BOD}_{5}$ of the proteins, starch and PVA before and after degradation in the activated sludge for 3 days. Concentration of the sizing agent in the activated sludge was $300 \mathrm{ppm}$. c) Total nitrogen released from the proteins and PVA during degradation in activated sludge. $\mathrm{d}$ Changes in ammonia nitrogen during the degradation of the proteins in activated sludge.

decreased the COD level for the proteins and starch and marginally for PVA. After 3 days of treatment, the COD values were lower than $100 \mathrm{mg} / \mathrm{L}$ (allowable concentration when effluent is discharged) for the gluten, soyproteins and starch and we therefore did not continue the degradation of the samples further. Even after 3 days, the chicken feather had only decreased in COD by about $55 \%$. COD of feather size continued to decrease but at a relatively much slower rate compared to the other two proteins studied. After 10 days of treatment, feather size had a COD of $140 \mathrm{mg} / \mathrm{L}$. Since the microorganisms in the sludge may not be active after 5 days, we added fresh sludge into the feather solution to observe if the feathers can further degrade. COD of the feather solutions did not decrease appreciably even with the addition of fresh sludge suggest- ing that some part of the feathers were difficult to degrade. Compared to PVA which only had about $30 \%$ decrease in COD after 3 days and to starch that had similar degradation to the wheat gluten and soyprotein size, the protein solutions can be considered biodegradable. Biodegradation of the PVA solution was not continued beyond 3 days because the $\mathrm{BOD}_{5}$ values showed that there was no or very little biodegradable material in the PVA solution.

Biochemical oxygen demand

Figure $5 \mathrm{~b}$ showed that the proteins and starch had high biodegradability compared to PVA. $\mathrm{BOD}_{5}$ before treating in activated sludge was high for both the gluten and soyproteins but considerably low for the 
feathers and PVA indicating that there were higher amounts of non-biodegradable material in the feathers and PVA. After treating for 3 days in the activated sludge, there was substantial decrease in the $\mathrm{BOD}_{5}$ for all the three proteins and starch indicating that the microorganisms in the sludge were able to degrade the proteins. $\mathrm{BOD}_{5} / \mathrm{COD}$ which indicated the biodegradability were $0.70,0.57,0.17,0.4$ and 0.04 for wheat gluten, soyprotein, feathers, starch and PVA, respectively. When the $\mathrm{BOD}_{5} / \mathrm{COD}$ values were compared for the individual sizing agents, it was apparent that PVA was non-biodegradable and feathers were considerably harder to degrade than the plant proteins since feathers are highly crosslinked proteins compared to soyproteins and wheat gluten.

\section{Total nitrogen}

Figure $5 \mathrm{c}$ depicted the changes in the total nitrogen released from the proteins and PVA during degradation in activated sludge. Starch used in this study did not show any detectable amounts of nitrogen release during degradation. The proteins had substantially higher nitrogen compared to PVA before degradation. Nitrogen in PVA should be from the additives (lubricants, defoaming agents) used to improve the performance of PVA. There is no apparent change in the nitrogen up to 3 days for wheat gluten and soyproteins whereas the nitrogen released from the feathers showed considerable decrease after 1 and 2 days in activated sludge. A sharp decrease in nitrogen levels was observed for all the proteins after the 4th day in the sludge and no further decrease was observed after day 6. We stopped measuring the nitrogen content after 6 days since there was no appreciable decrease in nitrogen from day 4 to day 6 and the ammonia nitrogen released was negligible. Total nitrogen from the PVA samples did not decrease even after 3 days of treatment in the activated sludge.

\section{Ammonia nitrogen}

Figure $5 \mathrm{~d}$ depicted the ammonia nitrogen released from the proteins before and during the degradation up to 3 days. Soyproteins and wheat gluten showed considerable increase in ammonia nitrogen at day 3 , corresponding to the sharp decline in COD and total nitrogen released at day 4 indicating that most of the proteins were degraded between 3 and 4 days of treat- ment in activated sludge. Compared to the plant proteins, feather had a gradual degradation and a low but consistent release of ammonia nitrogen up to 10 days of treatment. Overall, the total and ammonia nitrogen released from the proteins, including feathers, was considerably low and would not cause problems for the waste water treatment plants.

Comparison of the performance of the protein sizes with the starch and the PVA

A comparison of the performance of the protein sizes in terms of improving the cohesion of rovings at various percentage add-ons relative to starch and PVA is depicted in Figure 6. At low percentage addon, soyproteins provided slightly better cohesion to the rovings than the other sizes studied. Increasing the add-on continually increased the strength of the rovings, except of soyproteins and wheat gluten. Even at about $35 \%$ lower add-on (7.7 \%), rovings sized with soyprotein had higher strength than the rovings sized with wheat gluten and chicken feather $(11.7 \%$ addon) as seen from Figure 1a. Interestingly, PVA and starch provided similar improvements in strength to the cotton rovings at the different percentage add-ons studied. Feather size had a considerably different behavior compared to the other proteins. Strength improvement in feather treated cotton rovings was considerably lower even when the add-on was $10.8 \%$. A much higher add-on of about $13 \%$ was required for the feather size to obtain comparable strength

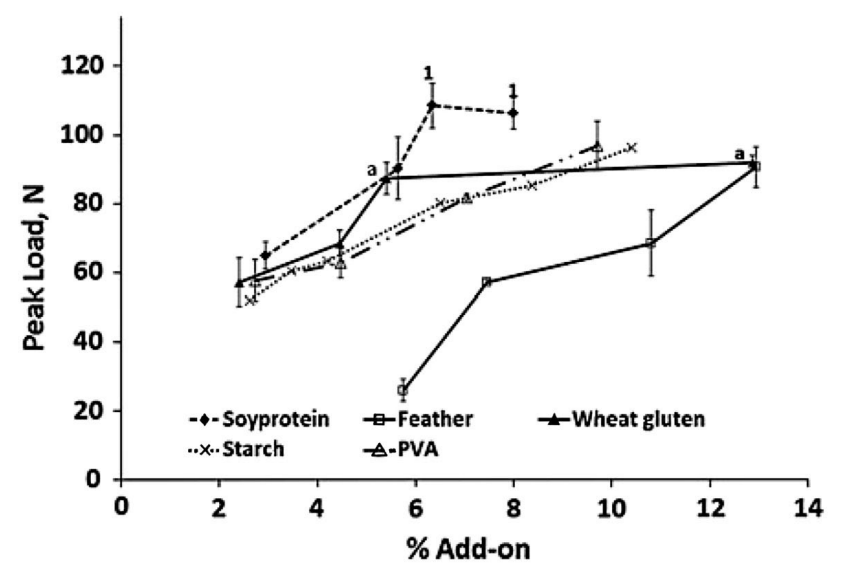

Figure 6. Comparison of the protein sizes with starch and PVA in terms of improvement in the tensile strength of the rovings at various percentage add-ons. For each size, a data point without any or with the same letter or symbol represents data points that are not statistically significantly different. 
improvements. Soyproteins- sized rovings had the highest strength of $109 \mathrm{~N}$ at an add-on of $6.4 \%$. Further increase in the add-on for the soyprotein sized rovings decreased the strength. Better performance of soyproteins in terms of improving the strength of the rovings is deemed to be due to the better film forming and adhesive properties of soyprotein. Feather were treated with relatively higher concentration of alkali that could have resulted in hydrolysis and lower molecular weight proteins and therefore inferior properties at low percentage add-on.

\section{Conclusion}

Based on the exploratory research conducted on cotton roving and fabrics, the plant proteins and poultry feathers may provide warp sizing performance (in weaving cotton yarns) comparable to that of traditional starch and PVA sizes. Furthermore, even at size concentrations of these so-called novel sizes twice higher than those commonly used in typical cotton textile plants, the proteins found in the desizing effluents in the treatment plants are easily biodegradable in activated sludge and do not release excess nitrogen that is detrimental to the degradation process. Soyproteins are able to improve the tensile properties and abrasion resistance of their coated (sized) cotton materials at considerably lower add-on percentages. The feather size may require use of higher percentage add-on to obtain similar improvements in cohesion and abrasion resistance of the sized material. Feather size was also relatively more difficult to degrade in the activated sludge. Feather-sized materials are affected by relative humidity to a higher extent than those sized with soyproteins and wheat gluten. Compared to PVA size, which has relatively higher price compared to starch and is also difficult to be degraded in activated sludge, the proteins studied in this research, especially the chicken feathers', offer a viable and economical alternative to replace starches, CMC, PVA and other substances used in traditional warp sizing. Unlike starch and plant proteins that are used for food and non-food applications, feathers only have limited applications and are low cost and currently disposed in landfills. Utilizing feathers as sizing agents is therefore expected to not only benefit the poultry and textile industries but also improve the environment.
Acknowledgments - The authors acknowledge financial support for this work from the Agricultural Research Division at the University of Nebraska-Lincoln, USDA Hatch Act, and Multi-State Project S1054 (NEB 37-037).

\section{References}

Abdel-Hafiz SA (1995) Accelerated oxidation of maize starch using the sodium chlorite/thiourea system. Polym Deg Stab 47:275-281

Anis P, Kayar HM, Eren HA (2007) Sizing agents recovery by ultrafiltration: effects of operating conditions. J Biol Environ Sci 1(2):93-98

Barclay S, Buckley C (2000) Waste minimisation guide for the textile industry. University of Natal, Durban

Chen L, Reddy N, Yang Y (2013) Soyproteins as environmentally friendly sizing agents to replace poly(vinyl alcohol). J Environ Poll Res. doi:10.1007/s11356-013-1601-5

Chen L, Reddy N, Yang Y (2013) Remediation of environmental pollution by substituting poly(vinyl alcohol) with biodegradable warp size from wheat gluten. Environ Sci Technol. doi:10.1021/es304429s

Dumitras PG, Sawhney APS, Bologa MK, Ghimza AV (2005) Influence of ultrasound cavitation on properties of starch size. Proc Surf Eng Appl Electrochem 1(9):83-89

El-Sawy NM, Abo-Shosha MH, Abd El-Ghaffar MA, Ibrahim NA (1993) Preparation of pol(AA)/PVA and poly(Aam)/ PVA composites and their use in sizing and resin finishing of cotton fabrics. Am Dyestuff Rep 82(10):60-63

El-Sheikh MA (2010) Carboxymethylation of maize starch at mild conditions. Carbohydr Polym 79:875-881

Goswami BC, Anandjiwala AD, Hall DM (2004) Textile sizing. Marcel Dekker, New York

Hamilton LE, Chiweshe A (1998) Textile pigment printing binders prepared by modifying wheat gluten with methyl acrylate. Starch/Stärke 50:213-218

Hari PK, Bhalla S (1986) Some studies on modified starch for low humidity application. Starch/Starke 38(9):301-305

Hari PK, Tewary A (1985) Role of moisture in the performance of sized yarns. Text Res J 55:567-571

Hebeish A, Abdel-Rahman A, El-Hilv Z, Hashem M (2005) Cationized starch derived from pre-oxidized starch for textile sizing and printing. Starch/Starke 57:616-623

Hebeish A, Aly AA, El-Shafei AM, Zaghloul S (2008) Innovative starch derivatives as textile auxiliaries for application in sizing, finishing and flocculation. Starch 60:97-109

Liu Y, Lv X, Hu X, Shan Z, Zhu P (2010) Effect of adding a small amount of high molecular weight polyacrylamide in properties of oxidized cassava starch. Carbohydr Polym 81:911-918

Marrot B, Roche N (2002) Wastewater treatment and reuse in textile industries, a review. Res Adv Water Res 3:41-53 
Mohamed ZE, Amr A, Knittel D, Schollmeyer E (2010) Synthesis and application of new sizing and finishing additives based on carboxymethyl cellulose. Carbohydr Polym 81:769-774

Mostafa KM (2003) Evaluation of nitrogen containing starch and hydrolyzed starch derivatives as a size base material for cotton yarns. Carbohydr Polym 51:63-68

Mostafa KM, Morsy MS (2004) Tailoring a new sizing agent via structural modification of pregelled starch molecules part I: carboxymethylation and grafting. Starch/Stärke 56:254-261

Reddy N, Yang Y (2007) Characterizing chicken feather barbs as natural protein fibers. J Polym Environ 15(2):81-87

Reddy N, Yang Y (2010) Light-Weight polypropylene composites reinforced with whole chicken feathers. J Appl Polym Sci 116:3668-3675

Reddy N, Yang Y (2011) Potential of plant proteins for medical application. Trends Biotechnol 29(10):490-498

Sawhney APS, Dumitras PG, Sachinvala ND, Calamari TA, Bologa MK, Singh KV (2005a) Research approaches for reducing or eliminating warp sizing in modern weaving: an interim report. AATCC Rev 5(9):23-26
Sawhney APS, Singh KV, Sachinvala N, Pang SS, Calamari TA, LI G (2005b) Mechanical analysis of weaving process towards size-free weaving. Beltwide Cotton Production and Research Conferences, National Cotton Council of America, pp 2706-2711

Shen D, Xue M, Zhang L, Liu H, Gao L, Cui Y (2011) Preparation and characterization of oxidized sesbania gum and evaluation of its warp sizing performance for fine cotton yarns. Carbohydr Polym 9(12):2181-2188

Tarakcioglu I (1986) Textile treatment and machines-Part 3. Aracular, Izmir

UNEP (United Nations Environment Programme) (1996) Cleaner production in textile wet processing. UNEP, France

Zhu Z, Lin X, Long Z, Wang Y (2008) Adhesion, film and antiflocculation behavior of amphoteric starch for warp sizing. AATCC Rev 8(4):38-43

Zhu Z, Li M, Jin E (2009) Effect of an allyl pretreatment of starch on the grafting efficiency and properties of allyl starch-g-poly(acrylic acid). J Appl Polym Sci 112:2822-2829 